\title{
Hybrid 訓練法による大腿四頭筋への筋力増強効果
}

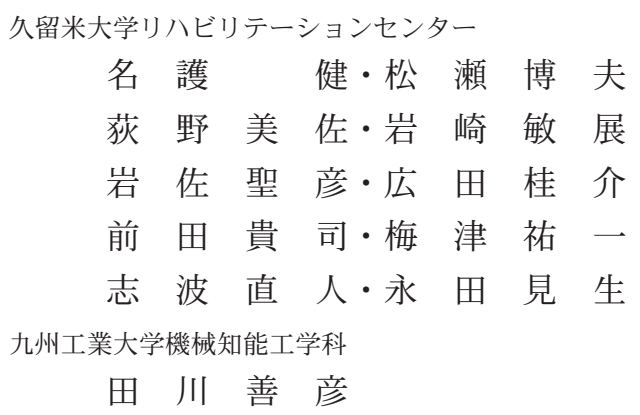

\section{Muscle Strengthening Effects of Hybrid Exercise on the Quadriceps Femoris}

Takeshi Nago, Hiroo Matsuse, Misa Ogino, Toshinori Iwasaki, Kiyohiko Iwasa, Keisuke Hirota,

Takeshi Maeda, Yuichi Umezu, Naoto Shiba, and Kensei Nagata

Kurume University Rehabilitation Center, Fukuoka, Japan

Yoshihiko Tagawa

Kyushu Institute of Technology, Fukuoka, Japan

\begin{abstract}
We developed a "hybrid exercise" technique that uses the force generated by an electrically stimulated antagonist muscle to provide resistance to a volitionally contracting agonist. In other words, the agonist performs volitional concentric contraction against an electrically stimulated eccentric contraction of the antagonist. Hybrid exercise has several advantages. These include; 1) activation of type I muscle fiber as a result of the volitional contraction of agonist muscles, 2) simultaneous exercise both agonist and antagonist musculatures, 3) longitudinal bone force loads, 4) requiring minimal external stabilization of the subjects, and 5) proven safety of the electrical stimulation as a physical therapy modality.
\end{abstract}

Key words : electrical stimulation (電気刺激), muscle strengthening (筋力増強), antagonist (拮抗筋)

\section{は じめに}

入院臥床による筋骨格系廃用変化は, 麻痺の無い患 者においても起こる各科共通のものであり, 早期離床, 早期社会復帰と密接に関係する.
れを主動作筋の抵抗とする新しい運動療法（Hybrid 訓練法：図 1) を考案し，上腕における種々の検討を 行い, 障害発生なく効率よく筋力が増強できることを 報告したが ${ }^{(6)}$, 廃用予防の臨床応用では, とくに下肢 における効果と安全性が重要である.

われわれは, 関節運動時に拮抗筋を電気刺激し, こ 
目

的

健常人における 6 週間の Hybrid 訓練法の, 大腿四 頭筋に対する筋力増強効果を検討する.

\section{対象と方 法}

久留米大学 IRB の承諾を受けた. 実験に先立ち, 被験者に対して実験に関する十分な説明を行った後, 実験実施の承諾を受けた。

対象：健常男性 12 名, 24 肢, 平均年齢 20 歳.

Hybrid 法：6 名 12 肢. 端座位膝屈伸運動に対し Hybrid 法（図 2）を行った。刺激条件は搬送周波数 $5,000 \mathrm{~Hz}$ ，刺激周波数 $20 \mathrm{~Hz}$ ，刺激強度は不快と感じ ない最大電圧とした．電極は大腿四頭筋（大腿直筋と

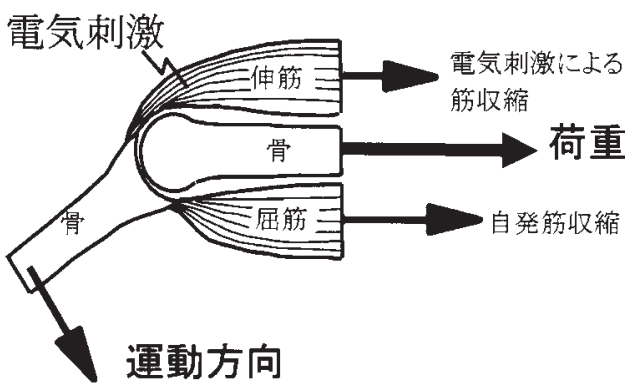

図 1 Hybrid 法の略図. 関節が屈曲運動するとき拮 抗筋の伸筋に電気刺激を与え収縮させる（伸展 運動では逆)。主動筋は求心性, 拮抗筋は電気 刺激による遠心性収縮する，挟まれた骨には長 軸方向に荷重が加わる.

\section{extension}

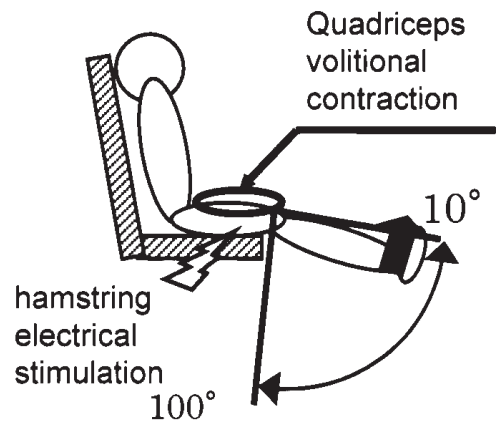

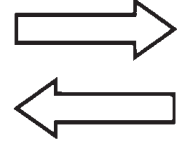

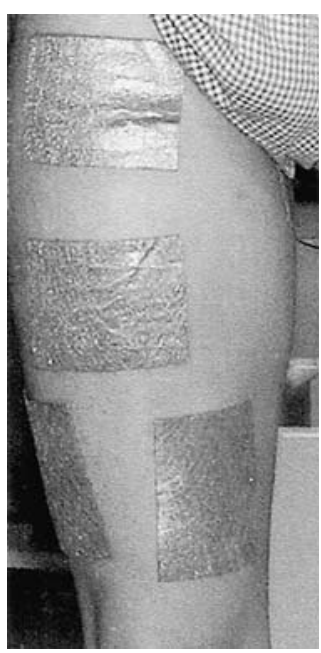

(a)

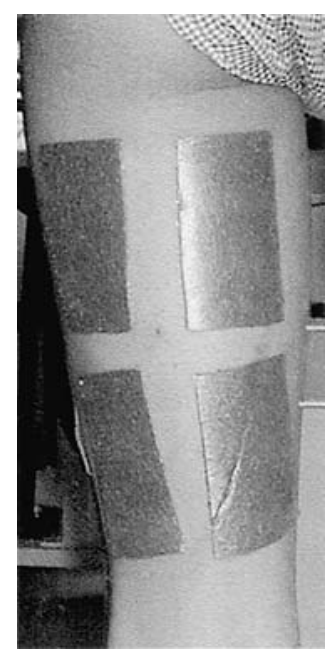

(b)
図 3 電極の貼付部位

（a）大腿四頭筋（大腿直筋，内側広筋，外側広筋）

（b）ハムストリング（内側，外側ハムストリングス）

\section{flexion}

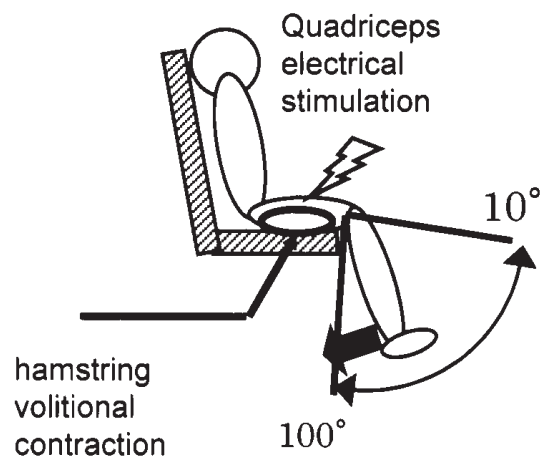

図 2 膝屈伸運動における Hybrid 訓練法 


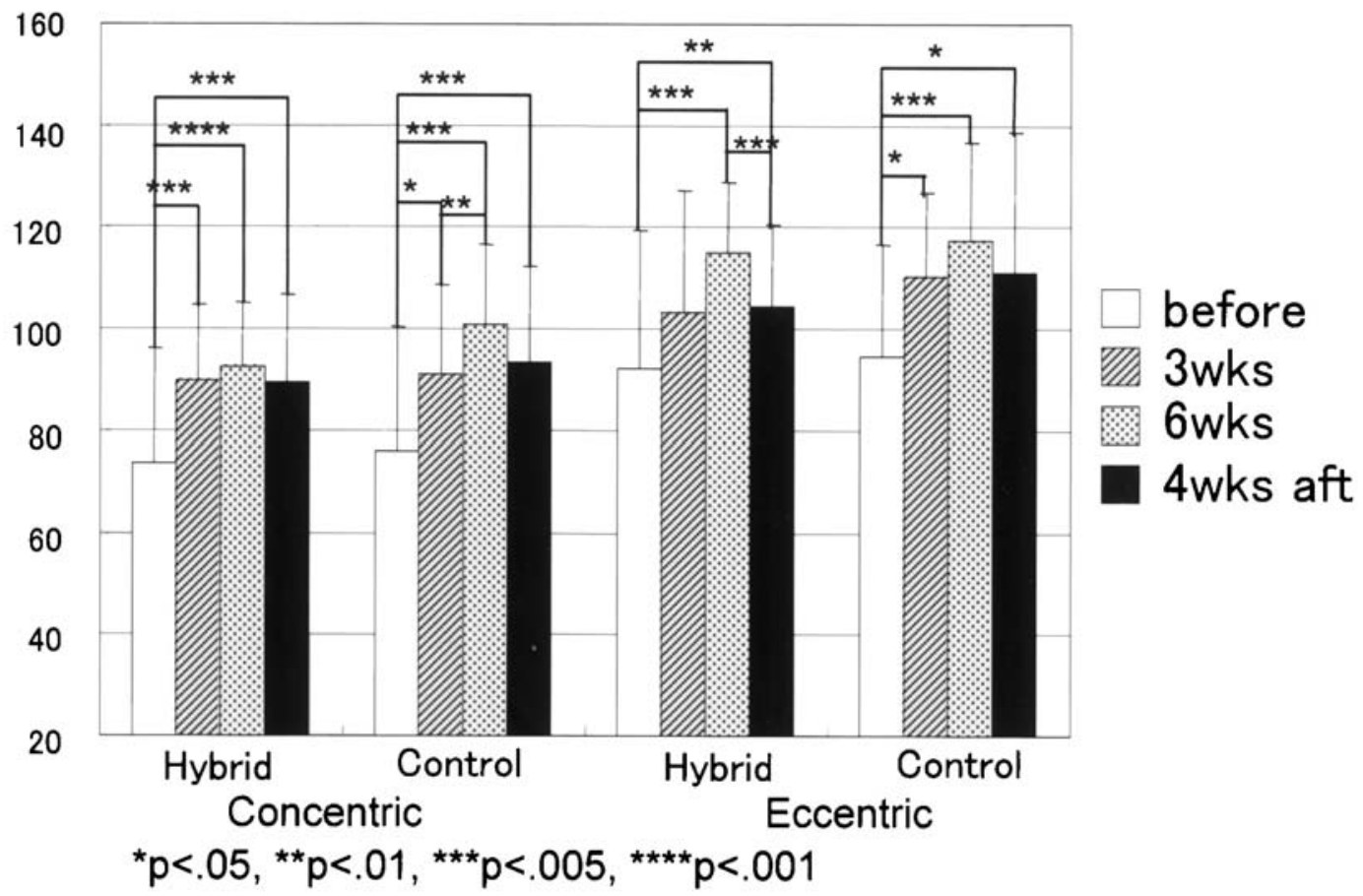

図 4 筋力測定結果

メディカルチェック：訓練時毎回医師が被験者の状 態を確認しながら実験を施行した.

筋力測定 : 膝伸展筋力測定には $\mathrm{KIN} / \mathrm{COM}$ を用い, 測定可動域は膝屈曲 10 度から 100 度までとした。求 心性及び遠心性収縮で角速度 $30^{\circ} / \mathrm{sec}$ の膝伸展筋力を 測定し, 3 回の平均值を求めた。刺激開始前, 刺激開 始 3 週経過後, 刺激終了時 (6 週後), 刺激終了 4 週 経過後の合計 4 回計測した.

統計：繰り返しのある分散分析法 (ANOVA) で, $\mathrm{p}$ が.05 以下を有意とした.

結果

メディカルチェック：全ての被験者が問題なく実験 を終了し, 障害の発生は無かった.

筋力測定 : 重錘と同等の筋力増強効果が得られた. 求心性収縮, 角速度 $30^{\circ} / \mathrm{sec}$ で Hybrid 法にて訓練開 始 3 週目で $22 \% \quad(\mathrm{p}<.005) ， 6$ 週目で $26 \% \quad(\mathrm{p}<.001)$ 増加, 重錘では, 3 週目で $19 \%(\mathrm{p}<.005), 6$ 週目で $32 \%(\mathrm{p}<.005)$ の増加を認めた。 訓練終了 4 週後そ れぞれ Hybrid 法 $22 \% \quad(\mathrm{p}<.005) ，$ コントロール 23\%（p＜.005）であった．同じく遠心性収縮では Hybrid 法にて訓練開始 3 週目で $12 \%$ (n.s.)， 6 週目 で $25 \% （ \mathrm{p}<.005 ）$ 増加した。重錘では，3 週目で $17 \%(\mathrm{p}<.05), 6$ 週目で $24 \% （ \mathrm{p}<.005 ）$ の増加を認 めた. 訓練終了 4 週後においてもそれぞれ Hybrid 法 13\% (n.s.), コントロール 18\% (p<.05) であった (図 4).

$$
\text { 考察 }
$$

先行研究で同じ刺激を与えるにも拘らず遠心性は求 心性を $50 \%$ 程度上回るトルクを発生することを明ら かにした ${ }^{4}$. Hybrid 法では比較的弱い刺激電流を用 いても遠心性収縮で大きな筋張力が得られ，同一電気 刺激を用いてもより有効な運動効果が得られる. 今回 実験に用いた刺激強度は大腿四頭筋，ハムストリング にそれぞれ求心性筋力を基準にして $27.20 \% \mathrm{MVC}$, 18.58\%MVCであり，これまで効果が無いとされて いた低い刺激強度となる ${ }^{1-3) 5)}$ 。これを Hybrid 法に使 用する条件, すなわち大腿四頭筋の電気刺激遠心収縮 は四頭筋自発遠心性収縮と比較して $31.64 \% \mathrm{MVC}$, 
大腿四頭筋の求心性収縮に対するハムストリングの電 気刺激遠心性筋力は $21.58 \% \mathrm{MVC}\left(30^{\circ} / \mathrm{sec}\right)$ であり, 訓練時間も休息を除くと実質 6 分 40 秒, 四頭筋, 八 ムストリングそれぞれの筋に対する電気刺激は 3 分 20 秒と極めて短時間であった.

Hybrid 訓練法は，(1)主動，拮抗両筋が同時収縮, (2)主動作筋は自発求心性収縮, 拮抗筋は電気刺激遠心 性収縮，(3)電気刺激が届かない深部筋は自発運動で収 縮する, (4)運動時骨長軸に荷重が加わる, (5)機器がコ ンパクト, 6電気刺激は医療に用いられる安全な技術, (7)電気刺激遠心性収縮は筋張力が大きく, より弱い刺 激電流を用いることができる，8個々の筋への電気刺 激は短時間, (9自発収縮を行うため遅筋線維も賦活す る, (10)重力に抗する運動ではなくても，拮抗筋の抵抗 により人工的に運動抵抗を作製でき, 体位を選ばない, などの特徵がある.

今後は本法の関節安定効果による膝十字勒帯損傷患 者への臨床応用や, 骨長軸荷重効果による大腿骨頸部 骨塩への影響について検討したい.

\section{ま と め}

(1) Hybrid 法と, 重錘法での筋力増強効果を比較し た.

(2) 6 週間の実験では，実験を中断するような傷害発 生は認めなかった.

(3)重錘による訓練とほぼ同等の筋力増強効果を認め ました。

(4) Hybrid 法では低電圧，短時間の電気刺激で筋力
増強が可能であった

(5) Hybrid 法は，大腿四頭筋においても有用な筋力 増強法であると考えられた。

本実験の一部は, 日本学術振興会科学研究費補助金 （課題番号 14350138）の援助を受けた。本実験は（財） 日本宇宙フォーラムが推進している「宇宙環境利用に 関する地上研究公募」プロジェクト「宇宙空間で有効 な筋力維持装置開発の研究」の一環として行った.

\section{参 考 文 献}

1) Balogum, J.A., et al.: High voltage electrical stimulation in the augmentation of muscle strength: Effect of pulse frequency. Arch. Pys. Med. Rehabil, $74:$ 910-916, 1993.

2) Delitto, A., et al.: Electrically elicited cocontraction of thigh musculature after anterior cruciate ligament surgery. A description and single-case experiment. Phys. Ther., 68(1) : 45-50, 1988.

3) Delitto, A., et al.: Electrical stimulation versus voluntary exercise in strengthening thigh musculature after anterior cruciate ligament surgery. Phys. Ther., 68(5) : 660-663, 1988.

4）岩崎敏展, 他：同一電気刺激による収縮形態の違いに よる筋出力差一長期間の電気刺激による刺激強度と筋出 力の変化一. 運動・物理療法, 15(1) : 32-37, 2004.

5) Richard, B.S., et al.: Biomechanics of human quadriceps muscles during electrical stimulation. J. of Biomec., 32 : 347-357, 1999.

6) Yanagi, T., et al.: Agonist Contractions Against Electrically Stimulated Antagonists. Arch. Phys. Med. Rehabil, 84(6) : 843-848, 2003. 